\title{
Comparison of elemental composition in two wild and cultured marine fish and potential risks to human health
}

\author{
Michel Marengo ${ }^{a}$, b, c, ${ }^{\text {, }}$ Eric Dominique Henry Durieux ${ }^{b}$, d, Sonia Ternengo ${ }^{b}$, d , Pierre Lejeune ${ }^{c}$, Elise Degrange ${ }^{a}$, \\ Vanina Pasqualini ${ }^{\mathrm{b}, \mathrm{d}}$, Sylvie Gobert ${ }^{\mathrm{a}, \mathrm{c}}$ \\ ${ }^{a}$ Université de Liège, Centre MARE, Laboratoire d'Océanologie, Sart-Tilman, B6c, 4000 Liège, Belgium \\ ${ }^{\mathrm{b}}$ Université de Corse Pascal Paoli, UMR 6134 CNRS-UCPP Sciences pour l'Environnement, 20250 Corte, France \\ c STAtion de REcherche Sous-marines et Océanographiques (STARESO), 20260 Calvi, France \\ ${ }^{\mathrm{d}}$ Université de Corse Pascal Paoli, UMS 3514 CNRS-UCPP Plateforme marine Stella Mare, 20620 Biguglia, France
}

\section{A R T I C L E IN F O}

\section{Keywords:}

Trace element

Aquaculture

Fisheries

Marine pollution

Target cancer risk

Hazard quotient

\begin{abstract}
A B S T R A C T
Among all available species, fish are a powerful model for risk-benefit assessments to study the effects of contaminants on human health. Gilthead seabream (Sparus aurata, Linnaeus 1758) and european seabass (Dicentrarchus labrax, Linnaeus 1758) are two species of great economic importance, representing very large production volumes in the Mediterranean. The objective of this study is (1) to analyze the concentrations of Trace Elements (TE) between wild and cultured seabream and seabass specimens, (2) to compare the determined concentrations with other studies, and (3) to increase the data about the potential risks to human health. Our results point to significant intra- and interspecies-specific differences between wild and cultured fish for several trace elements. Several strong and moderate inter-elemental correlations in fish muscle were observed through correlation analysis. In our study, the mean levels of trace elements were still below the standard safety values for fish intended for human consumption. The same results were reached for all the parameters analyzed (international legal limits, estimated weekly intake, provisional tolerable weekly intake, target hazard quotient, target cancer risk), with trace element levels in fish below those that could pose a risk to human health. Consequently, these fish can be considered safe for human consumption. A better understanding of the levels of trace elements in fish would also better inform consumers about the potential risks of exposure to contaminants.
\end{abstract}

\section{Introduction}

In recent years, there has been an increase in global fish consumption, mainly because human health benefits, such as the prevention of cardiovascular and other diseases (Lei et al., 2013). Likewise, fish are a good source of proteins and lipids of high biological value, with long-chain polyunsaturated fatty acids, liposoluble vitamins, and essential elements (Erkan and Özden, 2007; Mnari et al., 2012). At present, approximately $44 \%$ of the fish consumed by humans comes from aquaculture, and this percentage is predicted to reach $52 \%$ by 2025 (FAO, 2016). In spite of these advantages, the accumulation of trace elements in fish may pose a potential risk to human health (Medeiros et al., 2012). For a long time, however, pollution by trace elements (TE) of anthropogenic origin in the marine environment has been recognized as a serious threat to marine ecosystems (Dural et al., 2007).

Trace elements in the marine environment are either of natural origin (geochemical processes) or anthropogenic origin (e.g. agriculture, transport, mining, metalworking and pharmaceutical products) (Castritsi-Catharios et al., 2015).

In aquaculture, there may be additional sources of TE, such as copper-based antifoulings used to retard the build-up of fouling organisms, fish excreta, and/or fish pellets enriched with TE to meet their nutritional requirements (Sapkota et al., 2008). These elements due to their persistence, bioaccumulation and possible biomagnification in the food web represent a significant threat to marine organisms (Demirak et al., 2006; Uysal et al., 2009). Several factors can influence the bioaccumu-

* Corresponding author.

Email addresses: michel.marengo@laposte.net (M. Marengo); durieux@univ-corse.fr (E.D.H. Durieux); ternengo@univ-corse.fr (S. Ternengo); p.lejeune@stareso.com (P. Lejeune); elise. degrange@student.ulg.ac.be (E. Degrange); pasquali@univ-corse.fr (V. Pasqualini); sylvie.gobert@uliege.be (S. Gobert) 
lation of TE in fish tissues, such as environmental conditions (temperature, salinity, $\mathrm{pH}$ etc.), biological variations (species, sex, size and age), nourishment sources, and seasonal changes (Fallah et al., 2011).

The assimilation of TE by fish is carried out mainly by the ingestion of suspended particles in the water, ingestion of food, ion exchange of dissolved TE across lipophilic membranes (e.g., gills), and adsorption on tissue and membrane surfaces (Alam et al., 2002b). Some TE are essential for life (e.g. selenium, copper, cobalt, molybdenum, manganese, and zinc), with important nutritional functions that promote good health status in both fish and humans (Vandermeersch et al., 2015). However, other elements have no biological function (e.g. lead, cadmium, mercury, arsenic, tin, vanadium, and aluminum), and their consumption can cause adverse effects (e.g., renal dysfunction, lung disease, liver failure and dysfunctions in the kidneys, chronic damage to the central and peripheral nervous system) (Dadar et al., 2016; Squadrone et al., 2016). As they accumulate along the food chain, critical levels for human health can be reached (Yi et al., 2011). Thus, there is a growing interest in food safety with regard to the potential accumulation of these contaminants and its consequences (Lei et al., 2013). Fish represent an interesting model for risk-benefit assessments of the nature and probability of health effects in humans exposed to contaminants at present and in the future (Di Bella et al., 2015).

Gilthead seabream (Sparus aurata, Linnaeus 1758) and european seabass (Dicentrarchus labrax, Linnaeus 1758) are very important commercial species and are the two most widely farmed marine species in the Mediterranean Sea (Ferreira et al., 2010). Total fishery production (for both species) was $15,104 \mathrm{t}$ in 2014 , including a production of $6703 \mathrm{t}$ for gilthead seabream and $8401 \mathrm{t}$ for european seabass. Aquaculture production was $314,838 \mathrm{t}$, out of which $158,389 \mathrm{t}$ were seabream and 156,449t were seabass (FAO, 2017). Every year, between 400 and 600 million individual seabream and seabass are produced (Arechavala-Lopez et al., 2013). In the Mediterranean, their production has steadily increased in recent years, and these species are of great economic importance for the region (Squadrone et al., 2016). However, this intensive production in aquaculture generates many questions and concerns about the quality of farmed fish compared to wild fish (Alasalvar et al., 2002). For this reason, the assessment of differences in the quality of wild and farmed fish flesh is essential (Wang et al., 2014). It is therefore necessary to monitor and control the dangerous levels of fish contamination (Custódio et al., 2011).

The aim of this study is to examine the concentration of 19 trace elements ( $\mathrm{Ag}, \mathrm{Al}, \mathrm{As}, \mathrm{Ba}, \mathrm{Bi}, \mathrm{Cd}, \mathrm{Cr}, \mathrm{Cu}, \mathrm{Fe}, \mathrm{Li}, \mathrm{Mn}, \mathrm{Mo}, \mathrm{Pb}, \mathrm{Sb}, \mathrm{Se}, \mathrm{Sn}$, $\mathrm{U}, \mathrm{V}$, and $\mathrm{Zn}$ ) found in wild and farmed $S$. aurata and D. labrax collected from the Mediterranean Sea around Corsica. The study consisted of: (1) an analysis of the concentrations of trace elements in wild and cultured seabream and seabass specimens, (2) a comparison of the concentrations determined with those reported in other areas and with respect to international food safety regulations, and (3) enrichment of the data available on the potential risks to human health associated with the consumption of marine fish.

\section{Material and methods}

\subsection{Sample collection}

One-hundred and twenty fish [seabass $(n=60)$ and seabream $(n=60)$ ] have been studied from different origins (wild and farmed) ranging from 26 to $60 \mathrm{~cm}$ total length (TL). Fish collection was carried out from populations located off the Corsican coast (Northwestern Mediterranean). The sampling was conducted from October to December 2016. Various fish farms located along the Corsican coast provided the cultured specimens. The anonymity of the farms sampled is preserved, according to the wishes of the fish farmers. Catches of wild specimens were made by fishermen using nets mainly in the Biguglia and Urbino lagoons and were transported directly to the laboratory. The method of slaughter was immersion in ice-cold water (hypothermia) for both wild and farmed fish. The analyzes were performed on the muscles of the fish.

\subsection{Trace element analysis}

According to the method described by (Gobert et al., 2017; Richir and Gobert, 2014), samples (approximately $200 \mathrm{mg}$ ) were mineralized in Teflon digestion vessels, in a closed microwave digestion labstation (Ethos D, Milestone Inc. Sorisole, Italy), using $2 \mathrm{ml}$ of nitric acid $\left(\mathrm{HNO}_{3}\right.$, $60 \%)$ and $1 \mathrm{ml}$ of hydrogen peroxide $\left(\mathrm{H}_{2} \mathrm{O}_{2}, 30 \%\right)$ as reagents (suprapur grade, Merck, Darmstadt, Germany). Analyses of 19 trace elements (Ag, Al, As, Ba, Bi, Cd, Cr, Cu, Fe, Li, Mn, Mo, Pb, Sb, Se, Sn, U, V, $\mathrm{Zn}$ ) was conducted using inductively coupled plasma mass spectrometry using dynamic reaction cell technology (ICP-MS ELAN DRC II, PerkinElmer ${ }^{\circledR}$, Wellesley, United States). Analytical quality control was ensured using Certified Reference Materials (CRM), DORM-4: Fish protein and NIST 2976: Muscle tissue. Analysis of the CRM revealed a high level of agreement between the certified values for all TE (global mean recovery was $94 \pm 12 \%$ ). No certified values were reported for $\mathrm{Ba}, \mathrm{Bi}$, and Sb. For each TE, detection limit (LD) and quantification limit (LQ) were calculated, depending on their specific blank distribution (Currie, 1999). The detection limits in mg.kg ${ }^{-1}$ dry weight were: $\mathrm{Ag}=0.0011$; $\mathrm{Al}=0.0690 ; \mathrm{As}=0.0036 ; \mathrm{Ba}=0.0008 ; \mathrm{Bi}=0.0013 ; \mathrm{Cd}=0.0018$; $\mathrm{Cr}=0.0041 ; \mathrm{Cu}=0.0047 ; \mathrm{Fe}=0.1162 ; \mathrm{Li}=0.0018 ; \mathrm{Mn}=0.0010$; $\mathrm{Mo}=0.0014 ; \mathrm{Pb}=0.0037 ; \mathrm{Sb}=0.0024 ; \mathrm{Se}=0.0822 ; \mathrm{Sn}=0.0029 ; \mathrm{U}$ $=0.0001 ; \mathrm{V}=0.0009 ; \mathrm{Zn}=0.0208$. We converted our dry weight to wet weight data (using a conversion factor of 4) in order to compare with previously published studies (e.g. Anan et al., 2005). Our results are expressed in milligrams of element per kilogram of body wet weight (mg. $\mathrm{kg}^{-1} \mathrm{ww}$ ).

\subsection{Data analysis}

During data statistical treatment, for the samples with values below their analytical limit of detection (LD), half of the respective LD was substituted. Normality and homogeneity of variances were tested using Kolmogorov-Smirnov and Levene tests respectively. To better meet the assumptions of standard parametric statistical tests, to reduce the effect of outliers skewing the data distribution, and to bring elemental concentrations within the same range, the data were natural-log transformed (Gobert et al., 2017). To explore the differences in concentrations obtained from TE analysis, a multivariate analysis of variance (MANOVA) method was applied: species (2 levels: seabass/seabream) and fish origin (4 levels: farmed and wild for each species). To identify the influence of the factor on the response variables, when the MANOVA tests showed a significant effect, posteriori univariate ANOVA and post-hoc Tukey's honestly significant difference (HSD) tests were performed. To highlight the major TE differences between fish species and origins, the principal component analysis (PCA) was performed with TE concentrations as dependent variables. In addition, to investigate the relationship between the trace element levels (inter-element correlations) and the biological data (length), Pearson rank correlation tests were performed.

For example, high correlation between two TE implies that these two elements may share similar pollution sources or analogous transformation and migration processes in certain circumstances (Ragi et al., 2017). To determine the significance and strength of each relationship, the correlation coefficient ( $\mathrm{r}$ ) was calculated together with $p$-values. A significant difference was considered a $p$-value less than 0.05 . 
Analyses were performed using XLSTAT software (Addinsoft, Paris, France).

\subsection{Human risk assessment analysis}

\subsubsection{Metal pollution index (MPI)}

The Metal Pollution Index (MPI) method was used to compare the overall TE contents in the different fish studied. This index was obtained by calculating the geometrical mean of concentrations of all the TE (Usero et al., 1997).

$$
M P I=\left(C_{1} \times C_{2} \times C_{3} \times \ldots \times C_{n}\right)^{1 / n}
$$

where $C_{n}$ are the mean concentrations of trace element (n) in the examined tissue ( $\mathrm{mg} \mathrm{kg}^{-1}$ dry weight).

\subsubsection{Estimated intake}

Risk of TE intake (weekly) was estimated by calculating the respective levels found in fish, for a person weighing $70 \mathrm{~kg}$ and with a consumption rate of $427 \mathrm{~g}$ weekly (defined for European population) (FAO, 2016). The estimated intake was determined using the following equation:

$$
\text { Estimated Weekly Intake : EWI }=\left(C_{m} * I R_{w}\right) / \mathrm{BW}
$$

$C_{m}$ represents the TE concentration in fish $\left(\mu \mathrm{g} \mathrm{kg}^{-1}\right), I R_{w}$ the weekly ingestion rate $(\mathrm{kg})$, and $B W$ the body weight $(\mathrm{kg})$.

To assess public health risks, weekly fish intakes were compared with the Provisional Tolerable Weekly Intake (PTWI) recommended by the Joint FAO/WHO Expert Committee on Food Additives (FAO/WHO, 2011). The amount of contaminants that can be ingested over a lifetime can be estimated using this index which indicates appropriate and safe levels of exposure (Chamannejadian et al., 2013). Regulatory guidelines have been established by the European Food Safety Authority (EFSA) in which the PTWI of $\mathrm{Cd}$ and $\mathrm{Pb}$ is 7 and $25 \mu \mathrm{g} \mathrm{kg}{ }^{-1}$ week $^{-1}$, respectively. Furthermore, PTWI values were calculated for specific TE (As, Cr, Cu, $\mathrm{Fe}, \mathrm{Zn}$ ) and compared to regulatory limits.

\subsubsection{Target Hazard Quotients (THQ) and Target cancer Risk (TR)}

Based on the Target Hazard Quotient (THQ), non-carcinogenic health risks attributable to fish consumption were assessed (USEPA, 1989; Yi et al., 2011). The THQ is the ratio between exposure and reference doses (Reference Dose or RfD). A ratio lower than 1 indicates no obvious risk (Chien et al., 2002). Conversely, an exposed population will be subject to health risks if the dose is equal to or higher than the RfD (Amirah et al., 2013). A THQ value below 1 indicates that the level of daily exposure is unlikely to cause any adverse effects during a person's lifetime, although it also indicates potential non-carcinogenic effects (Jović and Stanković, 2014). In this study, total THQ was also assessed since humans are often exposed to more than one pollutant and can suffer combined or synergistic effects (Alamdar et al., 2017). The total THQ was calculated as the sum of the THQ values of the individual trace elements.

Regarding carcinogenic effects (inorganic As), risk is expressed by the model used for estimating carcinogenic Target Risk (TR) (USEPA, 2010; Vieira et al., 2011). The USEPA has provided a cancer slope factor only for inorganic arsenic, which is why As is the sole element evaluated in this study (Saha et al., 2016). The risk assessment of As was calculated only for its potentially toxic, inorganic form, which was estimated to be $10 \%$ of the total (Onsanit et al., 2010). Carcinogenic risks are estimated as the incremental probability of an individual developing cancer over their lifetime as a result of exposure to a potential risk factor (Ahmed et al., 2016). Acceptable lifetime cancer risk levels range from $10^{-4}$ (indicating a probability of a 1 in 10,000 chance of an individual developing cancer) to $10^{-6}$ (indicating a probability of a 1 in 0001000,000 chance of an individual developing cancer). There are four TR categories: TR $\leq 10^{-6}=$ low; $10^{-4}$ to $10^{-3}=$ moderate; $10^{-3}$ to $10^{-1}=$ high; and $\geq 10^{-1}=$ very high (Javed and Usmani, 2016).

The models for estimating THQ, TTHQ and TR are:

$$
\begin{aligned}
& T H Q=\left(E F r \times E D_{t o t} \times I R_{d} \times C\right) /(R f D \times B W \times A T) \\
& T T H Q=T H Q(T E 1) \\
& \quad+T H Q(T E 2)+T H Q(T E n) \\
& T R=\left(E F r \times E D_{t o t} \times I R_{d} \times C \times C P S o\right) /(B W \times A T)
\end{aligned}
$$

Where EFr is exposure frequency (365 days/year); $\mathrm{ED}_{\text {tot }}$ is the exposure duration (70 years, average lifetime); $\mathrm{IR}_{\mathrm{d}}$ is the food ingestion rate $\left(33.4 \times 10^{-3} \mathrm{~kg}\right.$ per day per person for the world); $\mathrm{C}$ is the TE concentration in fish $\left(\mathrm{mg} \mathrm{kg}^{-1}\right)$; RfD is the oral reference dose $(\mathrm{mg} / \mathrm{kg} /$ day) (Nadal et al., 2008; Storelli, 2008); BW is the average adult body weight (70 kg); and AT is the average exposure time for non-carcinogens (365 days per year x ED, assuming 70 years). CPSo is the oral carcinogenic slope factor from the Integrated Risk Information System (USEPA, 2010) database: $1.5(\mathrm{mg} / \mathrm{kg} / \text { day })^{-1}$ for As.

\section{Results}

Table 1 provides a summary of the mean concentrations of the 19 TE in the muscle of wild and cultured European seabass and Gilthead seabream.

The MANOVA results showed significant differences $\left(\mathrm{p}^{<} 0.001\right)$ in trace element accumulation patterns, mostly between the two species ( $S$. aurata/D. labrax) and their origins (wild/cultured). These results point to significant intra- and interspecies-specific differences between wild and cultured fish for several trace elements (Table 1). The comparison between wild and cultured $S$. aurata by the post hoc analysis (Tukey's multiple comparisons) revealed that there were significantly higher $(\mathrm{p}<0.05)$ concentrations of As, Se, and Bi as well as significantly lower ( $\mathrm{p}<0.05$ ) concentrations of $\mathrm{Ag}, \mathrm{Cu}$, and $\mathrm{Zn}$ in wild seabream. For $\mathrm{D}$. labrax, As, Li, Sb, and Sn concentrations in cultured fish were significantly higher than in wild fish. In contrast, $\mathrm{Ag}, \mathrm{Bi}$, and Se concentrations were significantly higher in wild fish than in cultured fish (Table 1). Comparing TE concentrations between the two species showed significant differences. For example, Li and Mo in the cultured $S$. aurata were significantly higher $(\mathrm{p}<0.05)$ than those in the wild D. labrax. On the other hand, $\mathrm{Ag}, \mathrm{Al}$, and $\mathrm{Bi}$ concentrations for wild $S$. aurata populations were lower than the mean levels for cultured $D$. labrax. In the present study, no significant differences in the concentrations of $\mathrm{Ba}, \mathrm{Fe}, \mathrm{Mn}$, or $\mathrm{U}$ were found between any populations $(\mathrm{P}>0.05)$.

Score plots from the PCA show the major trends in the observations and reveals variables with a significant loading. The first two principal components (PC1 and PC2) account for $26 \%$ and $14 \%$ of the overall variation of the data respectively (Fig. 1). The first principal component (PC1) based on the loading factors indicated an association with $\mathrm{Al}, \mathrm{Ba}, \mathrm{Cr}, \mathrm{Li}, \mathrm{Mn}, \mathrm{U}$, and $\mathrm{V}$. The second component had a significant factor loading for $\mathrm{As}, \mathrm{Bi}, \mathrm{Cu}, \mathrm{Pb}$, and $\mathrm{Sb}$. The samples presenting similar chemical characteristics are located in the same area of the score 
Table 1

Mean ( \pm standard deviation; SD) trace element concentrations ( $\mathrm{mg} \mathrm{kg}^{-1} \mathrm{ww}$ ) in the muscle of wild and cultured mediterranean European seabass and Gilthead seabream.

\begin{tabular}{|c|c|c|c|c|}
\hline Element & S. aurata $\mathrm{W}$ & S. aurata C & D. labrax $\mathrm{W}$ & D. labrax C \\
\hline $\mathrm{Ag}$ & $0.001( \pm 0.001)^{\mathrm{a}}$ & $0.001( \pm 0.001)^{\mathrm{b}}$ & $0.001( \pm 0.001)^{\mathrm{b}}$ & $0.001( \pm 0.001)^{\mathrm{a}}$ \\
\hline $\mathrm{Al}$ & $0.456( \pm 0.098)^{\mathrm{a}, \mathrm{b}}$ & $0.410( \pm 0.099)^{\mathrm{b}}$ & $0.646( \pm 0.119)^{\mathrm{a}}$ & $0.972( \pm 0.393)^{\mathrm{a}}$ \\
\hline As & $5.489( \pm 0.565)^{\mathrm{a}}$ & $2.739( \pm 0.572)^{b}$ & $1.030( \pm 0.198)^{\mathrm{c}}$ & $1.955( \pm 0.236)^{\mathrm{b}}$ \\
\hline $\mathrm{Ba}$ & $0.013( \pm 0.002)^{\mathrm{a}}$ & $0.027( \pm 0.008)^{\mathrm{a}}$ & $0.013( \pm 0.001)^{\mathrm{a}}$ & $0.029( \pm 0.011)^{\mathrm{a}}$ \\
\hline $\mathrm{Bi}$ & $0.001( \pm 0.001)^{\mathrm{a}}$ & $0.001( \pm 0.001)^{\mathrm{b}}$ & $0.003( \pm 0.001)^{\mathrm{c}}$ & $0.001( \pm 0.001)^{\mathrm{b}}$ \\
\hline $\mathrm{Cd}$ & $0.002( \pm 0.001)^{\mathrm{a}}$ & $0.004( \pm 0.002)^{\mathrm{a}, \mathrm{b}}$ & $0.001(0.001)^{\mathrm{b}}$ & $0.002( \pm 0.001)^{\mathrm{a}, \mathrm{b}}$ \\
\hline $\mathrm{Cr}$ & $0.020( \pm 0.002)^{\mathrm{a}}$ & $0.014( \pm 0.002)^{\mathrm{a}, \mathrm{b}}$ & $0.020( \pm 0.003)^{\mathrm{a}, \mathrm{b}}$ & $0.011( \pm 0.001)^{\mathrm{b}}$ \\
\hline $\mathrm{Cu}$ & $0.200( \pm 0.016)^{\mathrm{a}}$ & $0.497( \pm 0.137)^{\mathrm{b}}$ & $0.330( \pm 0.043)^{\mathrm{b}}$ & $0.440( \pm 0.034)^{\mathrm{b}}$ \\
\hline $\mathrm{Fe}$ & $2.171( \pm 0.129)^{\mathrm{a}}$ & $2.475( \pm 0.272)^{\mathrm{a}}$ & $3.115( \pm 0.331)^{\mathrm{a}}$ & $2.468( \pm 0.184)^{\mathrm{a}}$ \\
\hline $\mathrm{Li}$ & $0.010( \pm 0.001)^{\mathrm{a}, \mathrm{b}}$ & $0.017( \pm 0.002)^{\mathrm{a}}$ & $0.011( \pm 0.001)^{\mathrm{b}}$ & $0.013( \pm 0.001)^{\mathrm{a}}$ \\
\hline Mn & $0.142( \pm 0.020)^{\mathrm{a}}$ & $0.247( \pm 0.062)^{\mathrm{a}}$ & $0.136( \pm 0.010)^{\mathrm{a}}$ & $0.173( \pm 0.018)^{\mathrm{a}}$ \\
\hline Mo & $0.002( \pm 0.001)^{\mathrm{a}, \mathrm{b}}$ & $0.002( \pm 0.001)^{\mathrm{a}}$ & $0.001( \pm 0.001)^{\mathrm{b}}$ & $0.001( \pm 0.001)^{\mathrm{b}}$ \\
\hline $\mathrm{Pb}$ & $0.006( \pm 0.001)^{\mathrm{a}}$ & $0.013( \pm 0.009)^{\mathrm{a}, \mathrm{b}}$ & $0.003( \pm 0.001)^{\mathrm{b}, \mathrm{c}}$ & $0.003( \pm 0.001)^{\mathrm{c}}$ \\
\hline $\mathrm{Sb}$ & $0.035( \pm 0.006)^{\mathrm{a}}$ & $0.024( \pm 0.003)^{\mathrm{a}}$ & $0.234( \pm 0.060)^{\mathrm{b}}$ & $0.429( \pm 0.083)^{\mathrm{c}}$ \\
\hline Se & $0.228( \pm 0.011)^{\mathrm{a}}$ & $0.190( \pm 0.010)^{\mathrm{b}}$ & $0.307( \pm 0.011)^{\mathrm{c}}$ & $0.150( \pm 0.006)^{\mathrm{d}}$ \\
\hline $\mathrm{Sn}$ & $0.002( \pm 0.001)^{\mathrm{a}}$ & $0.004( \pm 0.002)^{\mathrm{a}}$ & $0.040( \pm 0.008)^{\mathrm{b}}$ & $0.056( \pm 0.003)^{\mathrm{c}}$ \\
\hline $\mathrm{U}$ & $0.001( \pm 0.001)^{\mathrm{a}}$ & $0.001( \pm 0.001)^{\mathrm{a}}$ & $0.001( \pm 0.001)^{\mathrm{a}}$ & $0.001( \pm 0.001)^{\mathrm{a}}$ \\
\hline V & $0.001( \pm 0.001)^{\mathrm{a}}$ & $0.001( \pm 0.001)^{\mathrm{a}, \mathrm{b}}$ & $0.001( \pm 0.001)^{\mathrm{a}, \mathrm{b}}$ & $0.001( \pm 0.001)^{\mathrm{b}}$ \\
\hline $\mathrm{Zn}$ & $3.551( \pm 0.202)^{\mathrm{a}}$ & $4.345( \pm 0.280)^{\mathrm{b}}$ & $4.221( \pm 0.165)^{b}$ & $3.819( \pm 0.122)^{\mathrm{a}, \mathrm{b}}$ \\
\hline
\end{tabular}

abcd Dissimilar letters denote significant differences between groups $\left(\mathrm{p}^{<} 0.05\right)$.

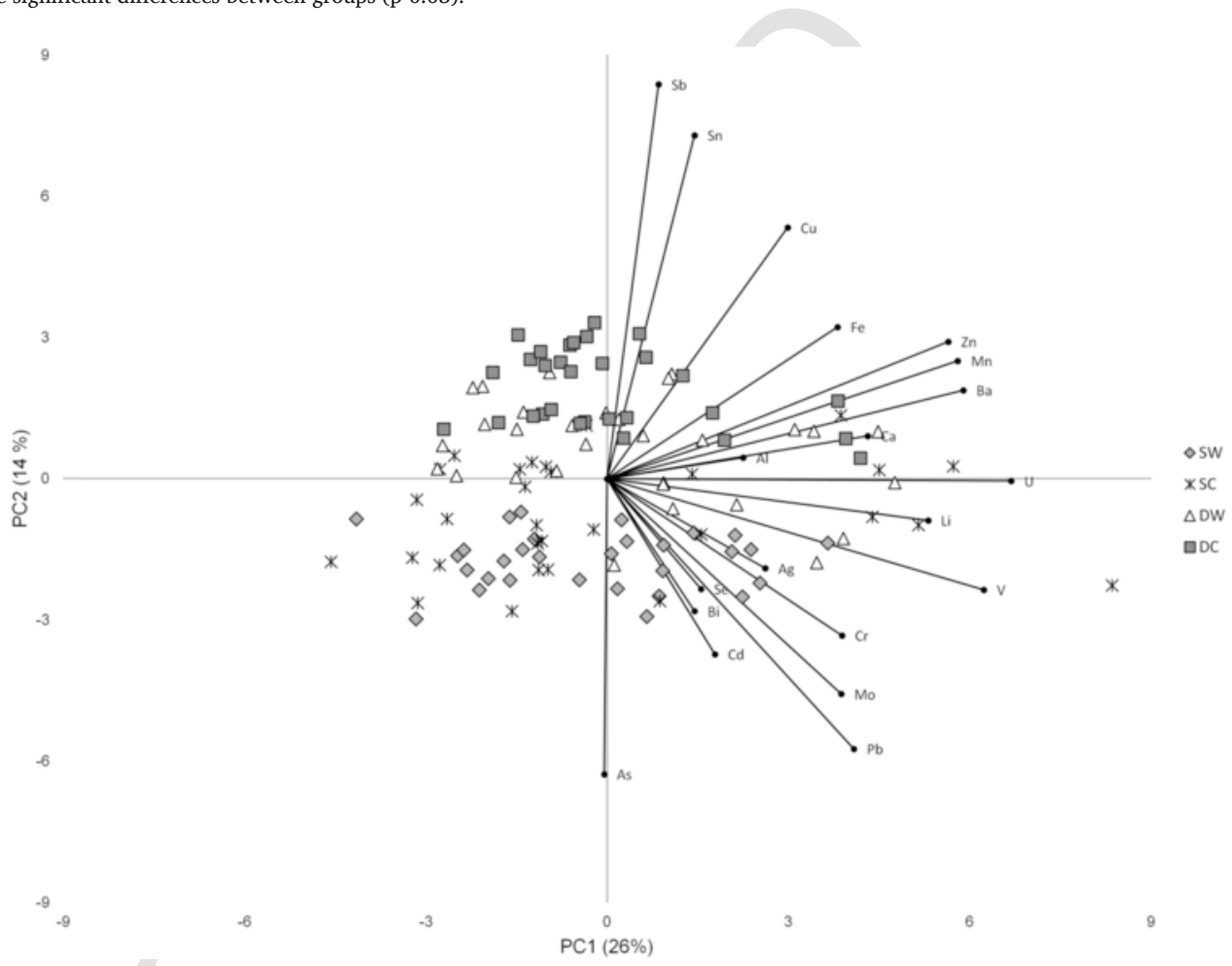

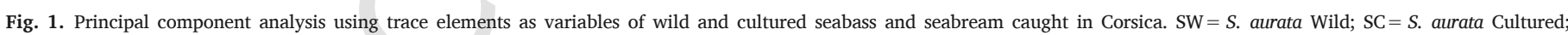
DW $=$ D.labrax Wild; DC $=$ D.labrax Cultured.

plot. As can be seen, the two species are clearly separated (S. aurata vs D. labrax).

The relationship between fish length and mean TE concentrations and the inter-element relationships has been studied. TE and the total length of cultured D. labrax showed no significant correlation ( $\mathrm{p}$ $>0.05$ ). Significant correlations between TE and total length were found in the other three groups (wild/cultured $S$. aurata and wild $D$. labrax) (Data in brief). Significant negative correlations were found between length and concentrations for $\mathrm{Cu}(\mathrm{p}<0.05)$ in wild $S$. aurata; for V ( $\mathrm{p}<0.05)$, Mn (p < 0.05), Zn ( $\mathrm{p}<0.05)$, and Li $(\mathrm{p}<0.01)$ in cultured aurata; and Se ( $\mathrm{p}<0.05), \mathrm{U}(\mathrm{p}<0.05)$, Fe ( $\mathrm{p}<0.05)$, Mo $(\mathrm{p}<0.05)$, and $\mathrm{Al}(\mathrm{p}<0.01)$ in wild $D$. labrax. In contrast, positive correlations with body size were found for As $(\mathrm{p}<0.01)$ in cultured $S$. aurata, as well as for $\mathrm{Sn}(\mathrm{p}<0.05)$ and $\mathrm{Sb}(\mathrm{p}<0.01)$ in wild D. labrax. Several strong and moderate inter-elemental correlations in fish muscle were observed through correlation analysis. For example, a strong correlation ( $\mathrm{p}<0.001$ ) exists between the element pairs $\mathrm{Pb}-\mathrm{Cu}, \mathrm{Mn}-\mathrm{U}$, and $\mathrm{Zn}-\mathrm{Li}$ in wild $S$. aurata; $\mathrm{Ag}-\mathrm{Bi}, \mathrm{Pb}-\mathrm{Mo}, \mathrm{Cd}-\mathrm{Pb}$, and $\mathrm{U}-\mathrm{Ba}$ in cultured $S$. aurata; $\mathrm{Al}-\mathrm{Mo}$ and $\mathrm{Sb}-\mathrm{Sn}$ in wild D. Labrax; and Al-Ba, $\mathrm{Pb}-\mathrm{V}$, and $\mathrm{Cu}-\mathrm{Fe}$ in cultured D. Labrax. 
The maximum levels set by international agencies for TE were used to assess the human risk associated with fish consumption. These levels were $95,0.3,1,20,10.2,0.3,2,250$, and $50 \mathrm{mg} \mathrm{kg}^{-1}$ for $\mathrm{Ba}, \mathrm{Cd}$, $\mathrm{Cr}, \mathrm{Cu}, \mathrm{Fe}, \mathrm{Pb}, \mathrm{Se}, \mathrm{Sn}$, and $\mathrm{Zn}$ respectively (E.U, 2008; MAFF, 2000; WHO, 2014). In our study, the mean levels of TE were still below the standard safety values for fish intended for human consumption. Concerning mean values for As, no comparison can be made since a legal limit does not exist for this element (Vieira et al., 2011). Metal pollution index (MPI) for each group was calculated and the values obtained showed a reasonably small range. Wild seabass showed higher values of MPI (0.189) than both farmed fish. Wild seabream showed the lowest metal pollution index (0.148). MPI values ranged from 0.148 to $0.189 \mathrm{mg} \mathrm{kg}^{-1}$.

The estimated weekly intake (EWI) values are presented in Table 2 and compared to recommended Provisional Tolerable Weekly Intake (PTWI). The results from Table 2 suggest that the EWI of As, Cd, Cr, Cu $\mathrm{Fe}, \mathrm{Pb}$, and $\mathrm{Zn}$ by a $70 \mathrm{~kg}$ adult consuming $427 \mathrm{~g}$ of fish/week were all below the limit set by European regulations.

The THQ and TTHQ values of TE by consuming fish for an individual adult are shown in Table 3 . The results show that the mean THQ and TTHQ values for cultured $S$. aurata and wild/cultured $D$. labrax are lower than 1. However, the THQ and TTHQ values for As are higher than 1 wild in $S$. aurata. Adverse effects on human health can be caused by inorganic arsenic as it contributes $91 \%$ of the TTHQ. The carcinogenic risk (TR), derived from the intake of As, was calculated since inorganic As is classified as a carcinogen. In the present study, the TR of inorganic As (calculated as the worst scenario: 10\% of the total determined As) (Table 3) exceeded the cancer risk benchmark

Table 2

The comparison between recommended values (PTWI) and the estimated weekly intakes (EWI) for wild and cultured seabass and seabream caught in Corsica. PTWI for $70 \mathrm{~kg}$ adult person in $\mu \mathrm{g} / \mathrm{week} / 70 \mathrm{~kg}$ body weight. EWI. in $\mu \mathrm{g} / \mathrm{week} / 70 \mathrm{~kg}$ body weight.

\begin{tabular}{|c|c|c|c|c|c|}
\hline Element & PTWI & $\begin{array}{l}S . \\
\text { aurata } \\
W\end{array}$ & $\begin{array}{l}S . \\
\text { aurata } \\
C\end{array}$ & $\begin{array}{l}D . \\
\text { labrax } \\
W\end{array}$ & $\begin{array}{l}\text { D. } \\
\text { labrax } \\
\text { C }\end{array}$ \\
\hline & & EWI & EWI & EWI & EWI \\
\hline As & 1050 & 3.34 & 1.67 & 0.62 & 1.18 \\
\hline Cd & 490 & 0.01 & 0.03 & 0.01 & 0.01 \\
\hline $\mathrm{Cr}$ & 44,590 & 0.04 & 0.08 & 0.02 & 0.02 \\
\hline $\mathrm{Cu}$ & 245,000 & 0.12 & 0.09 & 0.12 & 0.07 \\
\hline $\mathrm{Fe}$ & 392,000 & 1.22 & 3.04 & 2.02 & 2.69 \\
\hline $\mathrm{Pb}$ & 1750 & 13.25 & 15.10 & 19.00 & 15.06 \\
\hline $\mathrm{Zn}$ & 490,000 & 21.66 & 26.50 & 25.75 & 23.30 \\
\hline
\end{tabular}

$\left(10^{-6}\right)$ the benchmark most often used by the USEPA as the lower end of the range of acceptable risk (Vieira et al., 2011).

\section{Discussion}

This study was carried out to assess the risk to human health associated with the consumption of cultured versus wild fish. TE concentrations between fish species and origins (wild vs cultured) show significant differences. Physiological parameters may explain these results. The particularities identified in each species in the accumulation pattern of TE may be attributed to the functional difference of the respective membrane permeability, enzyme systems, and differences in metabolic activities of each fish (Omar et al., 2014). Moreover, this may be related to the differences in ecological needs, food source, habitat, type/level and time of exposure to pollution, environmental conditions, swimming behaviors, and growth rates of the organism (M. Alam et al., 2002a; Canli and Atli, 2003; Ricart et al., 2010).

Our results for seabass and seabream (wild and cultured) were either in the same order of magnitude or in the low range of contamination concentrations by TE, compared to those reported in the literature for the Mediterranean Sea (Alasalvar et al., 2002; Castritsi-Catharios et al., 2015; Custódio et al., 2011; Erkan and Özden, 2007; Ferreira et al., 2010; Lourenço et al., 2012; Özden and Erkan, 2008; Squadrone et al., 2016; Türkmen et al., 2010; Yabanli et al., 2012; Yildiz, 2008). The MPI contamination index was used which allows the evaluation of variations in TE between species and their origins. For the monitoring of TE pollution in food, the MPI can be used as a reliable and accurate method (Giri and Singh, 2017). The MPI is used to assess the degree of tissue contamination: the higher the index, the greater the contamination (Usero et al., 1997). In order to compare the localities according to the same bases, we calculated the MPI using TE values based on our study and previous works. Compared with previously published papers, the MPI values obtained were lower than the values of seabream and seabass in other localities in the Mediterranean Sea (Fig. 2). Thus the MPI of the fish in our study is lower than that of Italian, Greek, or Spanish fish (see Table 4). For both species, our study showed that TE levels were generally higher in wild specimens than in cultured ones. These higher TE concentrations in wild seabass and seabream as compared to farmed fish have been found in a number of previous studies (Alasalvar et al., 2002; Rožič et al., 2014). These results can be attributed to differences in diet or habitat type for the same species (Minganti et al., 2010a; Orban et al., 2002; Percin et al., 2011; Yildiz, 2008); however, the main route of TE accumulation in fish has been shown to be food (Wang and Rainbow, 2008).

Table 3

Target Hazard Quotient (THQ), Total THQ and Target cancer Risk (TR) from consumption by adults of wild and cultured seabass and seabream caught in Corsica.

\begin{tabular}{|c|c|c|c|c|c|c|c|c|c|}
\hline Element & RfD & THQ & & & & TR & & & \\
\hline & & S. aurata W & S. aurata C & D. labrax W & D. labrax C & S. aurata W & S. aurata C & D. labrax W & D. labrax C \\
\hline $\mathrm{Ag}$ & 0.005 & 0.001 & 0.001 & 0.001 & 0.001 & & & & \\
\hline As & 0.001 & 1.594 & 0.795 & 0.299 & 0.568 & 7.175E-04 & $3.581 \mathrm{E}-04$ & $1.347 \mathrm{E}-04$ & $2.556 \mathrm{E}-04$ \\
\hline $\mathrm{Cd}$ & 0.001 & 0.001 & 0.004 & 0.001 & 0.002 & & & & \\
\hline $\mathrm{Cr}$ & 0.003 & 0.005 & 0.004 & 0.005 & 0.003 & & & & \\
\hline $\mathrm{Cu}$ & 0.040 & 0.004 & 0.010 & 0.007 & 0.009 & & & & \\
\hline $\mathrm{Fe}$ & 0.700 & 0.002 & 0.003 & 0.003 & 0.003 & & & & \\
\hline $\mathrm{Mn}$ & 0.140 & 0.001 & 0.001 & 0.001 & 0.001 & & & & \\
\hline $\mathrm{Pb}$ & 0.003 & 0.001 & 0.003 & 0.001 & 0.001 & & & & \\
\hline $\mathrm{Se}$ & 0.005 & 0.039 & 0.033 & 0.053 & 0.026 & & & & \\
\hline Sn & 0.600 & 0.001 & 0.001 & 0.001 & 0.001 & & & & \\
\hline V & 0.001 & 0.001 & 0.001 & 0.001 & 0.001 & & & & \\
\hline \multirow[t]{2}{*}{$\mathrm{Zn}$} & 0.300 & 0.103 & 0.126 & 0.122 & 0.111 & & & & \\
\hline & TTHQ & 1.756 & 0.983 & 0.496 & 0.726 & & & & \\
\hline
\end{tabular}




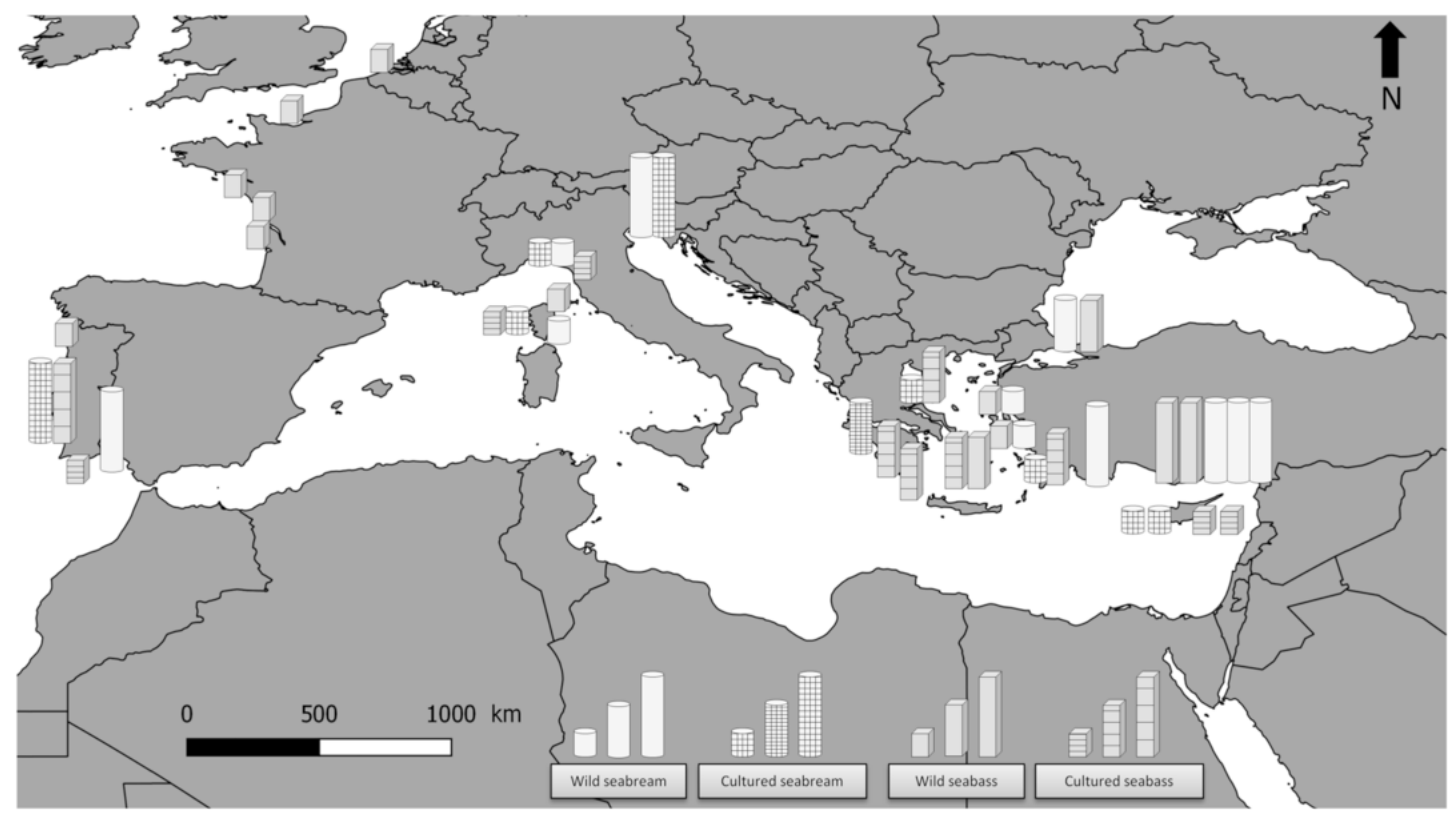

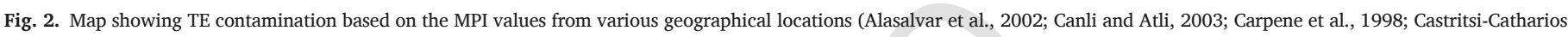

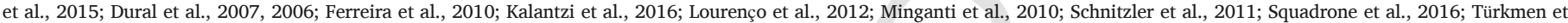

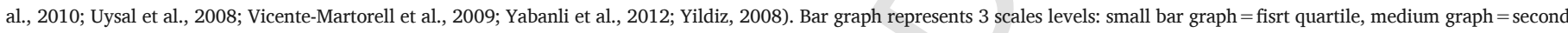
quartile, large graph $=$ third quartile.

Several factors can influence the bioavailability of TE from ingested food, such as: the nature of the food, the effectiveness of food assimilation, and the ingestion rate (Wong et al., 2001). Adult wild seabass and seabream are mainly carnivorous, capturing invertebrates, shrimps, crabs, mollusks, squids, and small fish, all of which have higher TE concentrations (Ferreira et al., 2010). In contrast, farmed fish usually have a shorter food chain as they are fed with fish pellets (Onsanit et al., 2010). Our results suggest that different aquaculture practices (e.g. location, organic and conventional aquaculture, composition of pellets) and other factors may influence TE accumulation patterns in our species (e.g. genetics, age, and physiological state) (Schenone et al., 2014). In short, the higher concentrations found in wild fish can be explained by three factors: (i) higher elemental concentrations in the natural environment of the wild stocks, (ii) the fact that muscle of cultured fish is likely richer in lipids which have a lower affinity for TE than the non-lipid compartments, and (iii) that wild fish are more active and thus express more protein contents (proximate composition) which has a high affinity for TE (Carpene et al., 1998; Fuentes et al., 2010). To a lesser extent, the concentrations of certain elements (e.g. $\mathrm{Bi}, \mathrm{Cu}, \mathrm{Zn}, \mathrm{Se}$ ) were higher in cultured individuals than in wild individuals.

One possible explanation is that, in addition to the natural presence of TE in the environment, additional sources of TE (e.g fish diets enriched with various essential elements as zinc, iron, manganese, and copper) (Lorentzen et al., 1998) may be added for nutritional purposes (Arechavala-Lopez et al., 2013). Thus, the higher TE concentrations observed in cultured fish for both species may be due to the release of TE from uneaten fish food, fish excreta, and antifouling chemicals used to prevent the development of fouling organisms in the nets (Basaran et al., 2010). Likewise, the habitats around the cages and, more specifically, the sediments can be enriched with these TE (Grigorakis and Rigos, 2011).

In terms of contaminants, fish quality may be influenced by site-specific environmental characteristics in addition to diet. The habitat may explain the differences in concentrations found, which are higher in the tissues of wild specimens than in cultured ones (Páez-Osuna and Tron-Mayen, 1996). Similarly, these differences could be due to differ- ent TE bioavailability in environments of variable salinity (lagoon vs sea) rather than an actual exposure to higher TE concentrations (Páez-Osuna and Tron-Mayen, 1996). Most wild fish were collected from a lagoon environment (Urbino and Biguglia), while the farmed fish were collected from an open marine bay (Munaron et al., 2013; Orsoni and Munaron, 2010). In the lagoon system, one of the major pathways of entry for TE could be erosion of natural deposits and/or domestic discharges into the river (Richir and Gobert, 2016). Besides urban effluents, agricultural activities on the banks and upstream could be an additional source of these TE (Luy et al., 2012). Soil enrichment through the use of fertilizers and pesticides containing toxic TE may also eventually end up in the river by runoff and erosion following rainfall (Bhowmik et al., 2015; Eqani et al., 2013).

Likewise, it has been shown that in this region there is a natural enrichment linked to the local mineralogical and geochemical context (Lafabrie et al., 2013; Pérez-Tribouillier et al., 2015; Shumilin et al., 2001). Considering the above, it is likely that wild and farmed fish are exposed to waters of different qualities.

Another objective of this work was to study the relationship between TE concentrations in fish and their length. In most cases, fish sizes and TE levels showed negative relationships. The difference in metabolic activity between younger and older fish may partly explain the negative relationship observed in our study. Young individuals tend to have higher metabolic activity than older ones (depuration of TE) (Storelli et al., 2007). The negative relationships between TE levels and fish size were generally supported in the literature (Burger et al., 2007; Gobert et al., 2017; Henry et al., 2004; Widianarko et al., 2000).

A positive relationship was identified between $\mathrm{Cd}, \mathrm{Cr}, \mathrm{Cu}, \mathrm{PB}$, and $\mathrm{Zn}$ and fish size which may be due to environmental transport and/or anthropogenic contributions

(Custódio et al., 2011). This could indicate that these TE (Cd, Cr, $\mathrm{Cu}, \mathrm{Pb}$ and $\mathrm{Zn}$ ) come from similar sources of pollution related to the study area, e.g. agricultural and domestic sewage discharge (Yi et al., 2011). The maximum levels recommended by international agencies for TE were used to assess the risk to humans associated with fish consumption (MAFF, 2000; USEPA, 2010; WHO, 2014). Whatever the case, the concentrations in TEs (Ba, Cd, Cr, Cu, Fe, Pb, Se, Sn, Zn) in 
Table 4

Calculated Metal Pollution Index (MPI) based on previous works from wild and cultured seabass and seabream worldwide.

\begin{tabular}{|c|c|c|c|c|c|}
\hline Country & Station & Species & Origin & MPI & References \\
\hline Belgium & Scheldt & Seabass & Wild & 0.77 & (Schnitzler et al., 2011) \\
\hline \multirow[t]{8}{*}{ France } & Charente & Seabass & Wild & 0.64 & \\
\hline & Gironde & Seabass & Wild & 0.61 & \\
\hline & Loire & Seabass & Wild & 0.67 & \\
\hline & Seine & Seabass & Wild & 0.63 & $>$ \\
\hline & Biguglia/Urbino & Seabass & Wild & 0.18 & Our study \\
\hline & Corsica & Seabass & Cultured & 0.18 & \\
\hline & Biguglia/Urbino & Seabream & Wild & 0.14 & \\
\hline & Corsica & Seabream & Cultured & 0.18 & 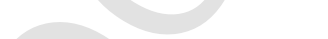 \\
\hline \multirow[t]{11}{*}{ Greece } & Volos & Seabream & Cultured & 0.46 & (Castritsi-Catharios et al., 2015) \\
\hline & & Seabass & Cultured & 1.87 & \\
\hline & AEG1 & Seabass & Cultured & 1.10 & (Kalantzi et al., 2016) \\
\hline & AEG2 & Seabass & Cultured & 0.59 & \\
\hline & ION1 & Seabass & Cultured & 1.36 & \\
\hline & ION2 & Seabass & Cultured & 1.06 & \\
\hline & AEG1 & Seabream & Cultured & 0.96 & \\
\hline & AEG2 & Seabream & Cultured & 1.04 & \\
\hline & ION2 & Seabream & Cultured & 1.72 & $>$ \\
\hline & Aegean Sea & Seabass & Wild & 1.50 & (Alasalvar et al., 2002) \\
\hline & Greek farm & Seabass & Cultured & 1.73 & \\
\hline \multirow[t]{5}{*}{ Italy } & Venice & Seabream & Wild & 5.84 & (Carpene et al., 1998) \\
\hline & & Seabream & Cultured & 4.71 & \\
\hline & Genova & Seabream & Wild & 0.78 & (Minganti et al., 2010b) \\
\hline & Cavi di Lavagna & Seabream & Cultured & 0.47 & \\
\hline & Porto Venere & Seabass & Cultured & 0.27 & (Squadrone et al., 2016) \\
\hline \multirow[t]{4}{*}{ Portugal } & Porto & Seabass & Wild & 0.17 & (Ferreira et al., 2010) \\
\hline & Ria Formosa & Seabass & Cultured & 0.11 & \\
\hline & Lisbon & Seabass & Cultured & 2.38 & (Lourenço et al., 2012) \\
\hline & & Seabream & Cultured & 2.21 & \\
\hline Spain & Ria de Huelva & Seabream & Wild & 2.11 & (Vicente-Martorell et al., 2009) \\
\hline \multirow[t]{14}{*}{ Turkey } & Karatas & Seabream & Wild & 3.95 & (Canli and Atli, 2003) \\
\hline & Camlik lagoon & Seabream & Wild & 3.41 & (Dural et al., 2006) \\
\hline & & Seabass & Wild & 4.44 & \\
\hline & Tuzla lagoon & Seabream & Wild & 1.96 & (Dural et al., 2007) \\
\hline & & Seabass & Wild & 1.44 & \\
\hline & Yelkoma Lagoon & Seabream & Wild & 4.80 & (Türkmen et al., 2010) \\
\hline & & Seabass & Wild & 2.28 & \\
\hline & Beymelek Lagoon & Seabream & Wild & 7.93 & (Uysal et al., 2008) \\
\hline & İzmir & Seabream & Wild & 0.10 & (Yabanli et al., 2012) \\
\hline & & Seabass & Wild & 0.13 & \\
\hline & Aegean Sea & Seabream & Wild & 0.80 & (Yildiz, 2008) \\
\hline & & Seabream & Cultured & 1.03 & \\
\hline & & Seabass & Wild & 0.67 & \\
\hline & & Seabass & Cultured & 1.12 & \\
\hline
\end{tabular}

both species were below the permissible safety limits for human consumption.

In the present study, complementary outcomes for human health risk assessment were obtained from several different approaches. Since the EWI values for the fish examined were far below the values established by various authorities (PTWI), it may be concluded that the consumption of these species does not pose a problem for human health (WHO, 2014). The EWI values of our study are consistent with the values given by previous studies (Ikem and Egiebor, 2005; Türkmen et al., 2010).

Carcinogenic TE can cause both carcinogenic (C) and noncarcinogenic (NC) effects in organisms, while NC TE only lead to noncarcinogenic effects (Varol et al., 2017).

Specific indices have been developed for noncarcinogenic and carcinogenic TE to assess possible human health risk from fish consumption (THQ, TTHQ, TR) (Copat et al., 2013). In the present study, Arsenic in wild $S$. aurata had the highest THQ value (1.5945). As such, consumption of these contaminated fish may cause adverse effects with long-term exposure. Thus, many biochemical processes can be disrupted by prolonged exposure to dangerous levels of TE, leading to cardiovascular, nervous system, kidney, skin and bone diseases (Giri and
Singh, 2017; Richir and Gobert, 2016). However, it must be kept in mind that THQ is a very conservative/restrictive standard and a relative index for assessing risks to human health (Wang et al., 2005). In reality, a THQ $>1$ may not actually result in people experiencing adverse health effects (Yi et al., 2011). The risk level to develop chronic systemic effects is zero; for the other three groups, the estimated THQs were less than 1 . Similarly the TTHQ were also less than 1 (except for $S$. aurata) as shown in the results. The estimation of the carcinogenic risk of inorganic arsenic was carried out by calculating the target cancer risk (TR) (USEPA, 2010).

Arsenic in marine organisms exists in two forms: organic and inorganic (arsenobetaine, arsenocholine, and organoarsenicals) (Raknuzzaman et al., 2016). Inorganic arsenic is considered the most toxic form (Sharma et al., 2014). As a conservative approach, it is estimated that the inorganic form represents $10 \%$ of the total arsenic (Francesconi, 2010). Many possible anthropogenic sources are responsible for inorganic arsenic found in the environment (e.g. herbicides, pesticides, fungicides, copperlead smelters, and glass manufactures) (Castro-González and Méndez-Armenta, 2008). The high levels of inorganic As found in fish from the Biguglia and Urbino lagoons can be explained by the leaching out of natural minerals. These ponds receive 
runoff from agricultural areas and flows from local rivers (Foata et al., 2009; Galgani et al., 2006).

The maximum limit for the acceptable risk of developing cancer has been set at $10^{-4}$ according to international agencies (USEPA, 2010). A moderate cancer risk ( $\mathrm{TR}^{<} 10^{-3}$ ) was detected in this study for the exposed population, as the TRs for all species were above the risk threshold. The risk associated with the carcinogenic effects of the target TE is expressed as the excess probability of contracting cancer over a lifetime of 70 years (Liang et al., 2011). Over long periods, continued consumption of these fish may represent a potential risk to the health of consumers. Like THQ, the estimated TR is a conservative value and does not represent a specific estimate of the expected cancers (Javed and Usmani, 2016). Rather, it is an upper limit of the probability that individuals may contract cancer at some time in their lifetimes following exposure to that toxicant (DOH, 2007).

All values for the cancer risk assessment with inorganic arsenic were greater than $10^{-4}$, indicating a moderate risk of cancer due to fish consumption. However, the worst case scenario (that inorganic arsenic accounted for $10 \%$ of the total arsenic) was tested. The best case scenario, as other studies have shown, is that inorganic arsenic in fish may represent only $2 \%$ of the total arsenic (Kalantzi et al., 2013). This method was previously used by Kalantzi et al., 2016. If these percentages are taken into account, the estimated carcinogenic risk of arsenic would still be above the limits $\left(10^{-4}\right)$ for wild $S$. aurata. The acceptable cumulative cancer risk for all the potentially carcinogenic contaminants was not exceeded by the TR values for the three other groups. Our results agree with those of other studies on fish, which found a higher risk due to arsenic (Ahmad et al., 2010; Alamdar et al., 2017; Kalantzi et al., 2016; Vieira et al., 2011).

In conclusion, the same results were reached for all the parameters analyzed (international legal limits, EWI, PTWI, THQ, TTHQ and TR), with TE levels in fish below those that could pose a risk for human health. Consequently, these fish can be considered safe for human consumption. The possible carcinogenic risks due to As must be taken into consideration especially in wild $S$. aurata which should be eaten in moderation. However, people should continue to consume fish and benefit from their positive health effects. The comparison between wild and cultured fish showed that TE concentrations were generally higher in wild specimens. However, our results showed relatively low contamination levels compared to other studies in the Mediterranean. This study significantly contributes to the database on contaminants available for these species. To prevent further degradation of the environment and to assess human exposure to contaminants, regular monitoring of TE levels in fish is required in the future. A better understanding of the levels of $\mathrm{TE}$ in fish would also better inform consumers about the potential risks of exposure to contaminants (Tepe, 2009).

\section{Uncited references}

Burger et al., 2001; Kojadinovic et al., 2007; Li et al., 2009; Saha and Zaman, 2013; Sipter et al., 2008.

\section{References}

Ahmad, M.K., Islam, S., Rahman, M.S., Haque, M.R., Islam, M.M., 2010. Heavy metals in water, sediment and some fishes of Buriganga River, Bangladesh. Int. J. Environ. Res. 4, 321-332.

Ahmed, M.K., Baki, M.A., Kundu, G.K., Islam, M.S., Islam, M.M., Hossain, M.M., 2016. Human health risks from heavy metals in fish of Buriganga river, Bangladesh. SpringerPlus 5, 1697.

Alam, M., Tanaka, A., Allinson, G., Laurenson, L.J.B., Stagnitti, F., Snow, E.T., 2002. A comparison of trace element concentrations in cultured and wild carp (Cyprinus carpio) of Lake Kasumigaura, Japan. Ecotoxicol. Environ. Saf. 53, 348-354.

Alam, M.G., Tanaka, A., Allinson, G., Laurenson, L.J., Stagnitti, F., Snow, E., 2002. A comparison of trace element concentrations in cultured and wild carp (Cyprinus carpio) of Lake Kasumigaura, Japan. Ecotoxicol. Environ. Saf. 53, 348-354. https://doi.org/10. 1016/S0147-6513(02)00012-X.
Alamdar, A., Eqani, S.A.M.A.S., Hanif, N., Ali, S.M., Fasola, M., Bokhari, H., Katsoyiannis, I.A., Shen, H., 2017. Human exposure to trace metals and arsenic via consumption of fish from river Chenab, Pakistan and associated health risks. Chemosphere 168, 1004-1012. https://doi.org/10.1016/j.chemosphere.2016.10.110.

Alasalvar, C., Taylor, K.D., Zubcov, E., Shahidi, F., Alexis, M., 2002. Differentiation of cultured and wild sea bass (Dicentrarchus labrax): total lipid content, fatty acid and trace mineral composition. Food Chem. 79, 145-150. https://doi.org/10.1016/ S0308-8146(02)00122-X.

Amirah, M.N., Afiza, A.S., Faizal, W.I.W., Nurliyana, M.H., Laili, S., 2013. Human health risk assessment of metal contamination through consumption of fish. J. Environ. Pollut. Hum. Health 1, 1-5.

Arechavala-Lopez, P., Fernandez-Jover, D., Black, K.D., Ladoukakis, E., Bayle-Sempere, J.T., Sanchez-Jerez, P., Dempster, T., 2013. Differentiating the wild or farmed origin of Mediterranean fish: a review of tools for sea bream and sea bass. Rev. Aquac. 5 , 137-157.

Basaran, A.K., Aksu, M., Egemen, O., 2010. Impacts of the fish farms on the water column nutrient concentrations and accumulation of heavy metals in the sediments in the eastern Aegean Sea (Turkey). Environ. Monit. Assess. 162, 439-451.

Bhowmik, A.K., Alamdar, A., Katsoyiannis, I., Shen, H., Ali, N., Ali, S.M., Bokhari, H., Schäfer, R.B., Eqani, S.A.M.A.S., 2015. Mapping human health risks from exposure to trace metal contamination of drinking water sources in Pakistan. Sci. Total Environ. 538, 306-316.

Burger, J., Gaines, K.F., Boring, C.S., Stephens, W.L., Snodgrass, J., Gochfeld, M., 2001. Mercury and selenium in fish from the Savannah River: species, trophic level, and locational differences. Environ. Res. 87, 108-118.

Burger, J., Gochfeld, M., Shukla, T., Jeitner, C., Burke, S., Donio, M., Shukla, S., Snigaroff, R., Snigaroff, D., Stamm, T., 2007. Heavy metals in Pacific cod (Gadus macrocephalus) from the Aleutians: location, age, size, and risk. J. Toxicol. Environ. Health A 70, 1897-1911.

Canli, M., Atli, G., 2003. The relationships between heavy metal (Cd, Cr, Cu, Fe, Pb, Zn) levels and the size of six Mediterranean fish species. Environ. Pollut. 121, 129-136. https://doi.org/10.1016/S0269-7491(02)00194-X.

Carpene, E., Martin, B., Dalla Libera, L., 1998. Biochemical differences in lateral muscle of wild and farmed gilthead sea bream (series Sparus aurata L.). Fish. Physiol. Biochem. 19, 229-238.

Castritsi-Catharios, J., Neofitou, N., Vorloou, A.A., 2015. Comparison of heavy metal concentrations in fish samples from three fish farms (Eastern Mediterranean) utilizing antifouling paints. Toxicol. Environ. Chem. 97, 116-123.

Castro-González, M.I., Méndez-Armenta, M., 2008. Heavy metals: implications associated to fish consumption. Environ. Toxicol. Pharmacol. 26, 263-271. https://doi.org/10. 1016/j.etap.2008.06.001.

Chamannejadian, A., Sayyad, G., Moezzi, A., Jahangiri, A., 2013. Evaluation of estimated daily intake (EDI) of cadmium and lead for rice (Oryza sativa L.) in calcareous soils. Iran. J. Environ. Health Sci. Eng. 10, 28.

Chien, L.-C., Hung, T.-C., Choang, K.-Y., Yeh, C.-Y., Meng, P.-J., Shieh, M.-J., Han, B.-C., 2002. Daily intake of TBT, $\mathrm{Cu}, \mathrm{Zn}, \mathrm{Cd}$ and As for fishermen in Taiwan. Sci. Total Environ. 285, 177-185. https://doi.org/10.1016/S0048-9697(01)00916-0.

Copat, C., Arena, G., Fiore, M., Ledda, C., Fallico, R., Sciacca, S., Ferrante, M., 2013. Heavy metals concentrations in fish and shellfish from eastern Mediterranean Sea: consumption advisories. Food Chem. Toxicol. 53, 33-37.

Currie, L.A., 1999. Nomenclature in evaluation of analytical methods including detection and quantification capabilities1: (IUPAC recommendations 1995). Anal. Chim. Acta 391, 105-126. https://doi.org/10.1016/S0003-2670(99)00104-X.

Custódio, P.J., Pessanha, S., Pereira, C., Carvalho, M.L., Nunes, M.L., 2011. Comparative study of elemental content in farmed and wild life Sea Bass and Gilthead Bream from four different sites by FAAS and EDXRF. Food Chem. 124, 367-372. https://doi.org/ 10.1016/j.foodchem.2010.06.020.

Dadar, M., Adel, M., Ferrante, M., Nasrollahzadeh Saravi, H., Copat, C., Oliveri Conti, G., 2016. Potential risk assessment of trace metals accumulation in food, water and edible tissue of rainbow trout (Oncorhynchus mykiss) farmed in Haraz River, northern Iran. Toxin Rev. 35, 141-146.

Demirak, A., Yilmaz, F., Tuna, A.L., Ozdemir, N., 2006. Heavy metals in water, sediment and tissues of Leuciscus cephalus from a stream in southwestern Turkey. Chemosphere $63,1451-1458$.

Di Bella, G., Potortì, A.G., Lo Turco, V., Bua, D., Licata, P., Cicero, N., Dugo, G., 2015. Trace elements in Thunnus thynnus from Mediterranean Sea and benefit-risk assessment for consumers. Food Addit. Contam. Part B 8, 175-181.

DOH, N., 2007. Hopewell precision area contamination: appendix C-NYS DOH. Proced. Eval. Potential Health Risks Contam. Concern.

Dural, M., Göksu, M.Z.L., Özak, A.A., 2007. Investigation of heavy metal levels in economically important fish species captured from the Tuzla lagoon. Food Chem. 102, 415-421. https://doi.org/10.1016/j.foodchem.2006.03.001.

Dural, M., Lugal Göksu, M.Z., Özak, A.A., Derici, B., 2006. Bioaccumulation of some heavy metals in different tissues of dicentrarchus labrax L, 1758, Sparus aurata L, 1758 And Mugil cephalus L, 1758 from the çamlik lagoon of the eastern cost of mediterranean (Turkey). Environ. Monit. Assess. 118, 65-74. https://doi.org/10. 1007/s10661-006-0987-7.

Eqani, S.A.-M.-A.-S., Malik, R.N., Cincinelli, A., Zhang, G., Mohammad, A., Qadir, A., Rashid, A., Bokhari, H., Jones, K.C., Katsoyiannis, A., 2013. Uptake of organochlorine pesticides (OCPs) and polychlorinated biphenyls (PCBs) by river water fish: the case of River Chenab. Sci. Total Environ. 450, 83-91. 
Erkan, N., Özden, , 2007. Proximate composition and mineral contents in aqua cultured sea bass (Dicentrarchus labrax), sea bream (Sparus aurata) analyzed by ICP-MS. Food Chem. 102, 721-725. https://doi.org/10.1016/j.foodchem.2006.06.004.

E.U, 2008. Commission regulation (EC) No. 629/2008 of 2 July 2008 amending regulation (EC) No. 1881/2006 setting maximum levels for certain contaminants in foodstuffs. Off. J. Eur. Union L 173, 6-9.

Fallah, A.A., Saei-Dehkordi, S.S., Nematollahi, A., Jafari, T., 2011. Comparative study of heavy metal and trace element accumulation in edible tissues of farmed and wild rainbow trout (Oncorhynchus mykiss) using ICP-OES technique. Microchem. J. 98, 275-279. https://doi.org/10.1016/j.microc.2011.02.007.

FAO, 2017. FISHSTAT J: FAO fishery and aquaculture global statistics.

FAO, 2016. La situation mondiale des pêches et de l'aquaculture 2016. Contribuer à la sécurité alimentaire et à la nutrition de tous. Rome.

FAO/WHO, 2011. Evaluation of Certain Food Additives and Contaminants: Seventy-third [73rd] Report of the Joint FA.

Ferreira, M., Caetano, M., Antunes, P., Costa, J., Gil, O., Bandarra, N., Pousão-Ferreira, P., Vale, C., Reis-Henriques, M.A., 2010. Assessment of contaminants and biomarkers of exposure in wild and farmed seabass. Ecotoxicol. Environ. Saf. 73, 579-588.

Foata, J., Quilichini, Y., Torres, J., Pereira, E., Spella, M.M., Mattei, J., Marchand, B., 2009. Comparison of arsenic and antimony contents in tissues and organs of brown trout caught from the river Presa polluted by ancient mining practices and from the river Bravona in Corsica (France): a survey study. Arch. Environ. Contam. Toxicol. 57, 581-589.

Francesconi, K.A., 2010. Arsenic species in seafood: origin and human health implications. Pure Appl. Chem. 82, 373-381.

Fuentes, A., Fernández-Segovia, I., Serra, J.A., Barat, J.M., 2010. Comparison of wild and cultured sea bass (Dicentrarchus labrax) quality. Food Chem. 119, 1514-1518. https: //doi.org/10.1016/j.foodchem.2009.09.036.

Galgani, F., Chiffoleau, J.-F., Orsoni, V., Costantini, L., Boissery, P., Calendini, S., Andral, B., 2006. Chemical contamination and sediment toxicity along the coast of Corsica. Chem. Ecol. 22, 299-312.

Giri, S., Singh, A.K., 2017. Human health risk assessment due to dietary intake of heavy metals through rice in the mining areas of Singhbhum Copper Belt, India. Environ. Sci. Pollut. Res. 1-12.

Gobert, S., Pasqualini, V., Dijoux, J., Lejeune, P., Durieux, E.D.H., Marengo, M., 2017. Trace element concentrations in the apex predator swordfish (Xiphias gladius) from a Mediterranean fishery and risk assessment for consumers. Mar. Pollut. Bull.

Grigorakis, K., Rigos, G., 2011. Aquaculture effects on environmental and public welfare-The case of Mediterranean mariculture. Chemosphere 85, 899-919.

Henry, F., Amara, R., Courcot, L., Lacouture, D., Bertho, M.-L., 2004. Heavy metals in four fish species from the French coast of the Eastern English Channel and Southern Bight of the North Sea. Environ. Int. 30, 675-683.

Ikem, A., Egiebor, N.O., 2005. Assessment of trace elements in canned fishes (mackerel, tuna, salmon, sardines and herrings) marketed in Georgia and Alabama (United States of America). J. Food Compos. Anal. 18, 771-787.

Javed, M., Usmani, N., 2016. Accumulation of heavy metals and human health risk assessment via the consumption of freshwater fish Mastacembelus armatus inhabiting, thermal power plant effluent loaded canal. SpringerPlus 5, 776.

Jović, M., Stanković, S., 2014. Human exposure to trace metals and possible public health risks via consumption of mussels Mytilus galloprovincialis from the Adriatic coastal area. Food Chem. Toxicol. 70, 241-251.

Kalantzi, I., Black, K.D., Pergantis, S.A., Shimmield, T.M., Papageorgiou, N., Sevastou, K., Karakassis, I., 2013. Metals and other elements in tissues of wild fish from fish farms and comparison with farmed species in sites with oxic and anoxic sediments. Food Chem. 141, 680-694. https://doi.org/10.1016/j.foodchem.2013.04.049.

Kalantzi, I., Pergantis, S.A., Black, K.D., Shimmield, T.M., Papageorgiou, N., Tsapakis, M., Karakassis, I., 2016. Metals in tissues of seabass and seabream reared in sites with oxic and anoxic substrata and risk assessment for consumers. Food Chem. 194, 659-670. https://doi.org/10.1016/j.foodchem.2015.08.072.

Kojadinovic, J., Potier, M., Le Corre, M., Cosson, R.P., Bustamante, P., 2007. Bioaccumulation of trace elements in pelagic fish from the Western Indian Ocean. Environ. Pollut. $146,548-566$

Lafabrie, C., Garrido, M., Leboulanger, C., Cecchi, P., Grégori, G., Pasqualini, V., Pringault, O., 2013. Impact of contaminated-sediment resuspension on phytoplankton in the Biguglia lagoon (Corsica, Mediterranean Sea). Estuar. Coast. Shelf Sci. 130, 70-80.

Lei, B., Chen, L., Hao, Y., Cao, T., Zhang, X., Yu, Y., Fu, J., 2013. Trace elements in animal-based food from Shanghai markets and associated human daily intake and uptake estimation considering bioaccessibility. Ecotoxicol. Environ. Saf. 96, 160-167.

Li, F., Fan, Z., Xiao, P., Oh, K., Ma, X., Hou, W., 2009. Contamination, chemical speciation and vertical distribution of heavy metals in soils of an old and large industrial zone in Northeast China. Environ. Geol. 57, 1815-1823.

Liang, C.-P., Liu, C.-W., Jang, C.-S., Wang, S.-W., Lee, J.-J., 2011. Assessing and managing the health risk due to ingestion of inorganic arsenic from fish and shellfish farmed in blackfoot disease areas for general Taiwanese. J. Hazard. Mater. 186, 622-628.

Lorentzen, M., Maage, A., Julshamn, K., 1998. Supplementing copper to a fish meal based diet fed to Atlantic salmon parr affects liver copper and selenium concentrations. Aquac. Nutr. 4, 67.

Lourenço, H.M., Afonso, C., Anacleto, P., Martins, M.F., Nunes, M.L., Lino, A.R., 2012. Elemental composition of four farmed fish produced in Portugal. Int. J. Food Sci. Nutr. 63, 853-859.
Luy, N., Gobert, S., Sartoretto, S., Biondo, R., Bouquegneau, J.-M., Richir, J., 2012. Chemical contamination along the Mediterranean French coast using Posidonia oceanica (L.) Delile above-ground tissues: a multiple trace element study. Ecol. Indic. 18, 269-277.

MAFF, 2000. Monitoring and Surveillance of Non-radioactive Contaminants in the Aquatic Environment and Activities Regulating the Disposal of Wastes At Sea. (No. 52), Aquatic Environment Monitoring. Center for Environment, Fisheries and Aquaculture Science, Lowestoft, UK.

Medeiros, R.J., dos Santos, L.M.G., Freire, A.S., Santelli, R.E., Braga, A.M.C., Krauss, T.M., Jacob, S., do, C., 2012. Determination of inorganic trace elements in edible marine fish from Rio de Janeiro State, Brazil. Food Control 23, 535-541.

Minganti, V., Drava, G., De Pellegrini, R., Siccardi, C., 2010. Trace elements in farmed and wild gilthead seabream, Sparus aurata. Mar. Pollut. Bull. 60, 2022-2025.

Minganti, V., Drava, G., De Pellegrini, R., Siccardi, C., 2010. Trace elements in farmed and wild gilthead seabream, Sparus aurata. Mar. Pollut. Bull. 60, 2022-2025.

Mnari, B., Zaghbib, S.F., Dhibi, M., Harzallah, H.J., Dabbou, S., El Cafsi, M., Hammami, M., Chaouch, A., 2012. Effects of different cooking methods on the mineral contents of wild and farmed sea bream (Sparus aurata). Int. J. Food Sci. Technol. 47, 1964-1969.

Munaron, D., Hubert, M., Gonzalez, J.-.L., Tapie, N., Budzinski, H., Guyomarch, J., Andral, B., 2013. PEPS LAG: Projet échantillonneurs passifs pour la surveillance de la contamination chimique des lagunes méditerranéennes.

Nadal, M., Ferre-Huguet, N., Marti-Cid, R., Schuhmacher, M., Domingo, J.L., 2008. Exposure to metals through the consumption of fish and seafood by the population living near the Ebro River in Catalonia, Spain: health risks. Hum. Ecol. Risk Assess. 14, 780-795.

Omar, W.A., Saleh, Y.S., Marie, M.-A.S., 2014. Integrating multiple fish biomarkers and risk assessment as indicators of metal pollution along the Red Sea coast of Hodeida, Yemen Republic. Ecotoxicol. Environ. Saf. 110, 221-231.

Onsanit, S., Ke, C., Wang, X., Wang, K.-J., Wang, W.-X., 2010. Trace elements in two marine fish cultured in fish cages in Fujian province, China. Environ. Pollut. 158, 1334-1342.

Orban, E., Lena, G.D., Nevigato, T., Casini, I., Santaroni, G., Marzetti, A., Caproni, R., 2002. Quality characteristics of sea bass intensively reared and from lagoon as affected by growth conditions and the aquatic environment. J. Food Sci. 67, 542-546.

Orsoni, V., Munaron, D., 2010. Caractérisation de la contamination de l'étang de Diana (Corse) par des produits phytosanitaires. Résultats Suivis 2011.

Özden, , Erkan, N., 2008. Comparison of biochemical composition of three aqua cultured fishes (Dicentrarchus labrax, Sparus aurata, Dentex dentex). Int. J. Food Sci. Nutr. 59, 545-557.

Páez-Osuna, F., Tron-Mayen, L., 1996. Concentration and distribution of heavy metals in tissues of wild and farmed shrimp Penaeus vannamei from the northwest coast of Mexico. Environ. Int. 22, 443-450.

Percın, F., Sogut, O., Altınelataman, C., Soylak, M., 2011. Some trace elements in front and rear dorsal ordinary muscles of wild and farmed bluefin tuna (Thunnus thynnus L. 1758) in the Turkish part of the eastern Mediterranean Sea. Food Chem. Toxicol 49, 1006-1010.

Pérez-Tribouillier, H., Shumilin, E., Rodríguez-Figueroa, G.M., 2015. Trace elements in the marine sediments of the La Paz lagoon, Baja California Peninsula, Mexico: pollution status in 2013. Bull. Environ. Contam. Toxicol. 95, 61-66.

Ragi, A.S., Leena, P.P., Cheriyan, E., Nair, S.M., 2017. Heavy metal concentrations in some gastropods and bivalves collected from the fishing zone of South India. Mar. Pollut. Bull. 118, 452-458.

Raknuzzaman, M., Ahmed, M.K., Islam, M.S., Habibullah-Al-Mamun, M., Tokumura, M. Sekine, M., Masunaga, S., 2016. Trace metal contamination in commercial fish and crustaceans collected from coastal area of Bangladesh and health risk assessment. Environ. Sci. Pollut. Res. 23, 17298-17310.

Ricart, M., Guasch, H., Barceló, D., Brix, R., Conceição, M.H., Geiszinger, A., de Alda, M.J.L., López-Doval, J.C., Muñoz, I., Postigo, C., 2010. Primary and complex stressors in polluted Mediterranean rivers: pesticide effects on biological communities. J. Hydrol. 383, 52-61.

Richir, J., Gobert, S., 2016. Trace elements in marine environments: occurrence, threats and monitoring with special focus on the costal mediterranean. J. Environ. Anal. Toxicol. 6 .

Richir, J., Gobert, S., 2014. A reassessment of the use of Posidonia oceanica and Mytilus galloprovincialis to biomonitor the coastal pollution of trace elements: new tools and tips. Mar. Pollut. Bull. 89, 390-406.

Rožič, , Dolenec, T., Baždarić, B., Karamarko, V., Kniewald, G., Dolenec, M., 2014. Element levels in cultured and wild sea bass (Dicentrarchus labrax) and gilthead sea bream (Sparus aurata) from the Adriatic Sea and potential risk assessment. Environ. Geochem. Health 36, 19-39.

Saha, N., Mollah, M.Z.I., Alam, M.F., Rahman, M.S., 2016. Seasonal investigation of heavy metals in marine fishes captured from the Bay of Bengal and the implications for human health risk assessment. Food Control 70, 110-118.

Saha, N., Zaman, M.R., 2013. Evaluation of possible health risks of heavy metals by consumption of foodstuffs available in the central market of Rajshahi City, Bangladesh. Environ. Monit. Assess. 185, 3867-3878.

Sapkota, A., Sapkota, A.R., Kucharski, M., Burke, J., McKenzie, S., Walker, P., Lawrence, R., 2008. Aquaculture practices and potential human health risks: current knowledge and future priorities. Environ. Int. 34, 1215-1226.

Schenone, N.F., Vackova, L., Fernandez Cirelli, A., 2014. Differential tissue accumulation of arsenic and heavy metals from diets in three edible fish species. Aquac. Nutr. 20, 364-371. 
Schnitzler, J.G., Thomé, J.P., Lepage, M., Das, K., 2011. Organochlorine pesticides, polychlorinated biphenyls and trace elements in wild European sea bass (Dicentrarchus labrax) off European estuaries. Sci. Total Environ. 409, 3680-3686.

Sharma, B., Singh, S., Siddiqi, N.J., 2014. Biomedical implications of heavy metals induced imbalances in redox systems. BioMed. Res. Int. 2014.

Shumilin, E., Páez-Osuna, F., Green-Ruiz, C., Sapozhnikov, D., Rodríguez-meza, G.D., Godinez-orta, L., 2001. Arsenic, antimony, selenium and other trace elements in sediments of the La Paz Lagoon, Peninsula of Baja California, Mexico. Mar. Pollut. Bull. 42, 174-178.

Sipter, E., Rózsa, E., Gruiz, K., Tátrai, E., Morvai, V., 2008. Site-specific risk assessment in contaminated vegetable gardens. Chemosphere 71, 1301-1307.

Squadrone, S., Brizio, P., Stella, C., Prearo, M., Pastorino, P., Serracca, L., Ercolini, C., Abete, M.C., 2016. Presence of trace metals in aquaculture marine ecosystems of the northwestern Mediterranean Sea (Italy). Environ. Pollut. 215, 77-83.

Storelli, M.M., 2008. Potential human health risks from metals ( $\mathrm{Hg}, \mathrm{Cd}$, and $\mathrm{Pb}$ ) and polychlorinated biphenyls (PCBs) via seafood consumption: estimation of target hazard quotients (THQs) and toxic equivalents (TEQs). Food Chem. Toxicol. 46, 2782-2788.

Storelli, M.M., Barone, G., Piscitelli, G., Marcotrigiano, G.O., 2007. Mercury in fish: concentration vs. fish size and estimates of mercury intake. Food Addit. Contam. 24, 1353-1357.

Tepe, Y., 2009. Metal concentrations in eight fish species from Aegean and Mediterranean Seas. Environ. Monit. Assess. 159, 501-509.

Türkmen, A., Türkmen, M., Tepe, Y., Çekiç, M., 2010. Metals in tissues of fish from Yelkoma Lagoon, northeastern Mediterranean. Environ. Monit. Assess. 168, 223-230.

USEPA, 2010. Risk-based Concentration Table. Region 3. Philadelphia, PA.

USEPA, 1989. Risk Assessment Guidance for Superfund, Volume I. Human Health Evaluation Manual Part A, Interim Final. (EPA/ 540/1-89/002). United States Environmental Protection Agency, Washington, DC.

Usero, J., Gonzalez-Regalado, E., Gracia, I., 1997. Trace metals in the bivalve molluscs Ruditapes decussatus and Ruditapes philippinarum from the Atlantic Coast of Southern Spain. Environ. Int. 23, 291-298.

Uysal, K., Emre, Y., Köse, E., 2008. The determination of heavy metal accumulation ratios in muscle, skin and gills of some migratory fish species by inductively coupled plasma-optical emission spectrometry (ICP-OES) in Beymelek Lagoon (Antalya/ Turkey). Microchem. J. 90, 67-70. https://doi.org/10.1016/j.microc.2008.03.005.

Uysal, K., Köse, E., Bülbül, M., Dönmez, M., Erdoğan, Y., Koyun, M., Ömeroğlu, , Özmal, F., 2009. The comparison of heavy metal accumulation ratios of some fish species in Enne Dame Lake (Kütahya/Turkey). Environ. Monit. Assess. 157, 355-362.

Vandermeersch, G., Lourenço, H.M., Alvarez-Muñoz, D., Cunha, S., Diogène, J., Cano-Sancho, G., Sloth, J.J., Kwadijk, C., Barcelo, D., Allegaert, W., 2015. Environmental cont- aminants of emerging concern in seafood-European database on contaminant levels. Environ. Res. 143, 29-45.

Varol, M., Kaya, G.K., Alp, A., 2017. Heavy metal and arsenic concentrations in rainbow trout (Oncorhynchus mykiss) farmed in a dam reservoir on the Firat (Euphrates) River: risk-based consumption advisories. Sci. Total Environ. 599, 1288.

Vicente-Martorell, J.J., Galindo-Riaño, M.D., García-Vargas, M., Granado-Castro, M.D., 2009. Bioavailability of heavy metals monitoring water, sediments and fish species from a polluted estuary. J. Hazard. Mater. 162, 823-836.

Vieira, C., Morais, S., Ramos, S., Delerue-Matos, C., Oliveira, M., 2011. Mercury, cadmium, lead and arsenic levels in three pelagic fish species from the Atlantic Ocean: intra-and inter-specific variability and human health risks for consumption. Food Chem. Toxicol. 49, 923-932.

Wang, W.-X., Rainbow, P.S., 2008. Comparative approaches to understand metal bioaccumulation in aquatic animals. Comp. Biochem. Physiol. Part C Toxicol. Pharmacol. 148, 315-323.

Wang, X., Sato, T., Xing, B., Tao, S., 2005. Health risks of heavy metals to the general public in Tianjin, China via consumption of vegetables and fish. Sci. Total Environ. 350, 28-37.

Wang, Y., Yu, S., Ma, G., Chen, S., Shi, Y., Yang, Y., 2014. Comparative study of proximate composition and amino acid in farmed and wild Pseudobagrus ussuriensis muscles. Int. J. Food Sci. Technol. 49, 983-989.

WHO, 2014. Summary report Proceedings of the seventy-third meeting of JECFA. Joint FAO/WHO Expert Committee on Food Additives, Geneva, Switzerland. Geneva, 17-26 June 2014.

Widianarko, B., Van Gestel, C.A.M., Verweij, R.A., Van Straalen, N.M., 2000. Associations between trace metals in sediment, water, and guppy, Poecilia reticulata (Peters), from urban streams of Semarang, Indonesia. Ecotoxicol. Environ. Saf. 46, 101-107.

Wong, C.K., Wong, P.P.K., Chu, L.M., 2001. Heavy metal concentrations in marine fishes collected from fish culture sites in Hong Kong. Arch. Environ. Contam. Toxicol. 40, 60-69.

Yabanli, M., Alparslan, Y., Baygar, T., 2012. Assessment of cadmium, mercury and lead contents of frozen Eurorean sea bass (Dicentrarchus labrax L., 1758) and gilthead sea bream (Sparus aurata L., 1758) fillets from Turkey. Agric. Sci. 3, 669.

Yi, Y., Yang, Z., Zhang, S., 2011. Ecological risk assessment of heavy metals in sediment and human health risk assessment of heavy metals in fishes in the middle and lower reaches of the Yangtze River basin. Nitrogen Depos. Crit. Loads Biodivers. 159, 2575-2585. https://doi.org/10.1016/j.envpol.2011.06.011.

Yildiz, M., 2008. Mineral composition in fillets of sea bass (Dicentrarchus labrax) and sea bream (Sparus aurata): a comparison of cultured and wild fish. J. Appl. Ichthyol. 24, 589-594. 